Journal of Agricultural Sciences
(Tarim Bilimleri Dergisi)

\title{
A GIS Based Land Suitability and Gross Value Evaluation of Mined Lands in Şanlıurfa District
}

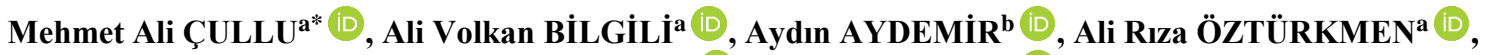 \\ Ahmet ALMACA ${ }^{\text {a }}$, Sema KARAKAŞ ${ }^{\mathrm{a}}$ \\ ${ }^{a}$ Department of Soil Science, Agriculture Faculty, Harran University, Sanliurfa, TURKEY \\ $\boldsymbol{b}_{\text {Şanliurfa Metropolitan Municipality, Şanliurfa, TURKEY }}$ \\ ARTICLE INFO \\ Research Article \\ Corresponding Author: Mehmet Ali ÇULLU, E-mail: macullu@ harran.edu.tr \\ Received: 15 April 2020 / Revised: 15 September 2020 / Accepted: 21 September 2020 / Online: 20 January 2022
}

\section{ABSTRACT}

Landmined areas are located along the borders of Sanliurfa province between Turkey and Syria with $220 \mathrm{~km}$ length and $400 \mathrm{~m}$ width. Governmental institutions attempted to determine the potential and suitability of mined lands for any agricultural activities before removing active mines. The research was conducted to estimate land suitability and gross value for irrigated agricultural production (GVIAP) of the mined areas using the database for the surrounding land and data obtained by Geographic Information Systems (GIS) techniques. The study was conducted in three steps; data including soil characteristics, digital elevation model (DEM) and orthophoto images of lands located $2 \mathrm{~km}$ nearby the mined land along the Turkish border were collected. The data containing DEM and orthophoto images of mined and adjacent lands were integrated in the second step. Finally, a field survey was conducted along the border district and soil samples were collected for each soil boundary nearby the mined lands. The integration of data in GIS allowed to expand the soil boundaries from adjacent lands into the mined lands. Data analysis showed that the total mined land is 6706 hectares of which $90.2 \%$ is highly and moderately suitable, $6.9 \%$ is less suitable and $2.9 \%$ is not suitable for irrigated agriculture. The gross value of irrigated agricultural production was estimated as 2212 US Dollars per hectare. The results revealed that the integration of inaccessible land database with the remote sensing data and GIS can be used to estimate the gross value which is derived from soil characteristics of the mined lands.

Keywords: Gross value added, Adjacent data, Mined lands, Land evaluation, Syria border, Landmined areas

(C) Ankara University, Faculty of Agriculture

\section{Introduction}

Conservation and appropriate use of available land resources have gained much attention and became crucial because of global warming and land degradation. The decrease in the agricultural lands due to the pressure of increasing population and degraded soil quality threatens future food production and safety.

The conversion of primary farmlands to urban sprawl and other uses has increasingly become a local, regional, and national concern in Turkey (Kılıç 2011; Bilgili et al. 2018). Turkey is highly vulnerable to drought and desertification due to the various climate, soil characteristics, and topographical structures (Camcı Çetin et al. 2007; OSB 2016). Lands and land uses have a close relationship, therefore, inappropriate and unplanned land management cause irretrievable damage to the lands which eventually turn into useless for agricultural activities (FAO 1977). Land suitability assessment is a prerequisite step of land use planning that is the fitness of a region for different land use types (FAO 1976; FAO 2007 ), which assists land users in decision-making regarding the level of land suitability (Pramanik 2016; Yalew et al. 2016). Land suitability assessment is often used to manage land resources properly and determine the most appropriate land use type for a particular area (Bodaghabadi et al. 2015). Knowledge on the land suitability is an important tool in planning sustainable land management and integrating the information with crop and soil requirements. Land suitability maps for specific purposes (Gallo et al. 2014) can be obtained by the use of integrating spatial data in GIS (Zhang et al. 2007).

Landmines have been placed between Turkey and Syria borders in 1957 for security and preventing smuggling purposes. Therefore, these lands became inaccessible and closed to all activities. Recently, the need for determination agricultural potential of the mined lands in the Şanlıurfa district has arisen in order for providing data for future planning of agricultural uses. Thus, the objective of this study is to determine the land suitability classes and to estimate gross value of irrigated agricultural production of landmined area by the available data of adjacent lands and mined areas using the GIS techniques. 


\section{Material and Methods}

\subsection{Description of the study area}

The research was conducted at the mined border belt of Şanlıurfa province located along the $220 \mathrm{~km}$ southern border between Turkey and Syria. The width of the mined area is approximately $400 \mathrm{~m}$ wide, comprising a total of 6706 ha (Figure 1).

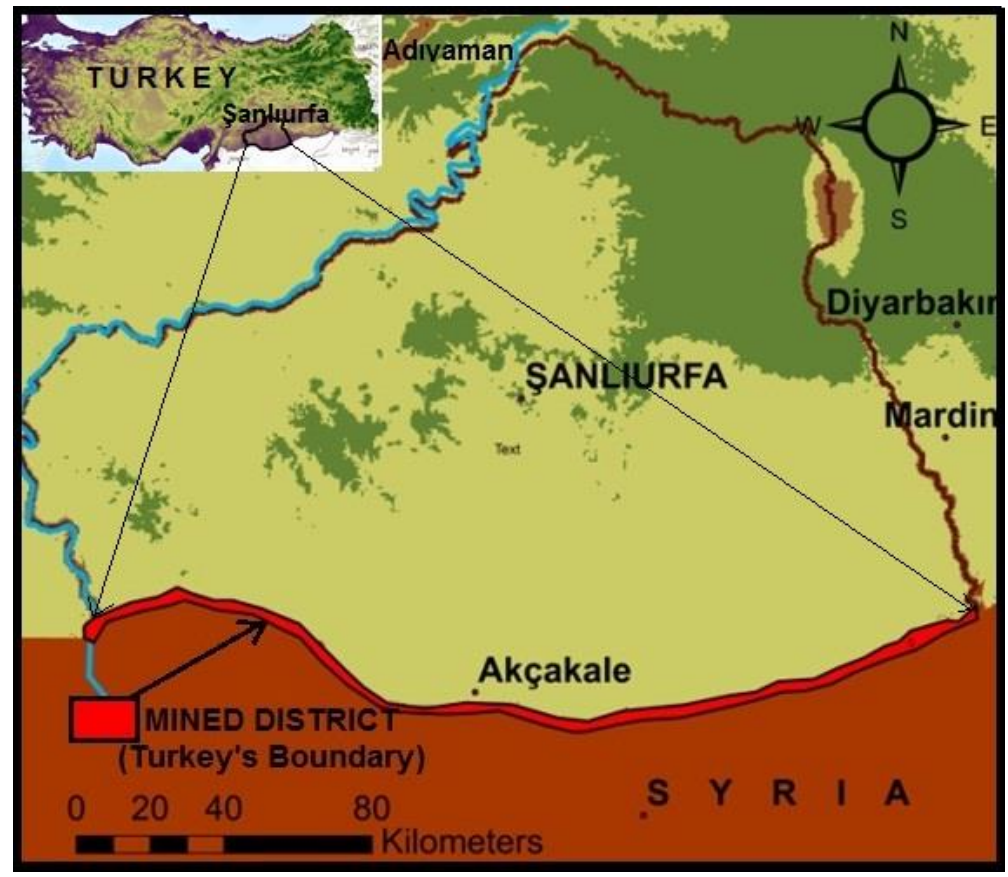

Figure 1- Location of the study area

The dominant climate of the study area is Eastern Mediterranean with a strong continental influence characterized by dry summers. The evaporation reaches $2000 \mathrm{~mm}$, the average temperature is $18.4{ }^{\circ} \mathrm{C}$ and the average annual precipitation is approximately $442 \mathrm{~mm}$ (DMI 2011). The soil moisture regime is Xeric and the temperature regime is mesic (Soil Survey Staff 2010). The dominant soils within the region are classified as Leptosols, Vertisols, Cambisols, and Calcisols (Çullu et al. 2018) according to IUSS Working Group WRB (2015). The soils are high in pH levels and moderate to high in $\mathrm{CaCO}_{3}$ content. The cation exchange capacity (CEC) is high, organic matter content is low and most soils are clayey in texture (Çullu et al. 2010). Geology of the study area comprises mainly clayey deposits, limestone, sandy marl, shallow marine deposits and the mudflow materials transported during the Pleistocene climatic fluctuation from the surrounding mountains (Kapur et al. 1991).

\subsection{Method}

\subsubsection{Data collection and GIS analysis}

The available database was compiled for an area of $2 \mathrm{~km}$ wide strip along the border belt, beginning from Turkish territory extending to the mined areas to determine the land suitability classes and to estimate gross value of irrigated agricultural production (GVIAP) of the mined area. The database of mined belt along the borderline, within Turkey, including the former soil map, digital elevation model (DEM) and orthophoto images were integrated into GIS. Soil boundaries, attribute soil data of the adjacent lands of the mined area (Dinç et al. 1988; KHGM 1995) and elevation contours of standard topographic maps were digitized using ArcGIS software (ESRI Inc 2008). A DEM was created by the interpolation of 5 to 50 -m interval contour lines digitized from the topographic maps. A slope gradient map was derived from the DEM using standard filtering techniques and classified into five categories. Vector and ancillary data about soil and topography maps were loaded into the GIS by screen digitization and keyboard entry. High resolution-orthophoto image interpretations (1:10.000 scaled) were also used as the reference data for visual interpretation of the soil boundary distributions continuity through the mined land. The study was conducted in three steps;

Database of lands within a $2 \mathrm{~km}$ distance of the mined belt within Turkey, including soil polygons and attributes (depth, texture, salinity, organic matter, $\mathrm{pH}$ and lime content), slope map and orthophoto images interpretation were firstly generated. A file containing slope map and orthophoto image of mined and adjacent lands were compiled and integrated into GIS in the second step. Finally, a soil survey was carried out by using the analysis of the database along the border to determine the continuity of soil boundary through the mined lands. Soil samples were collected and analysed (texture, salinity, organic matter and $\mathrm{pH}$ content averages given in the Table 1) from each soil polygons. The flow chart of the study is shown in Figure 2. 


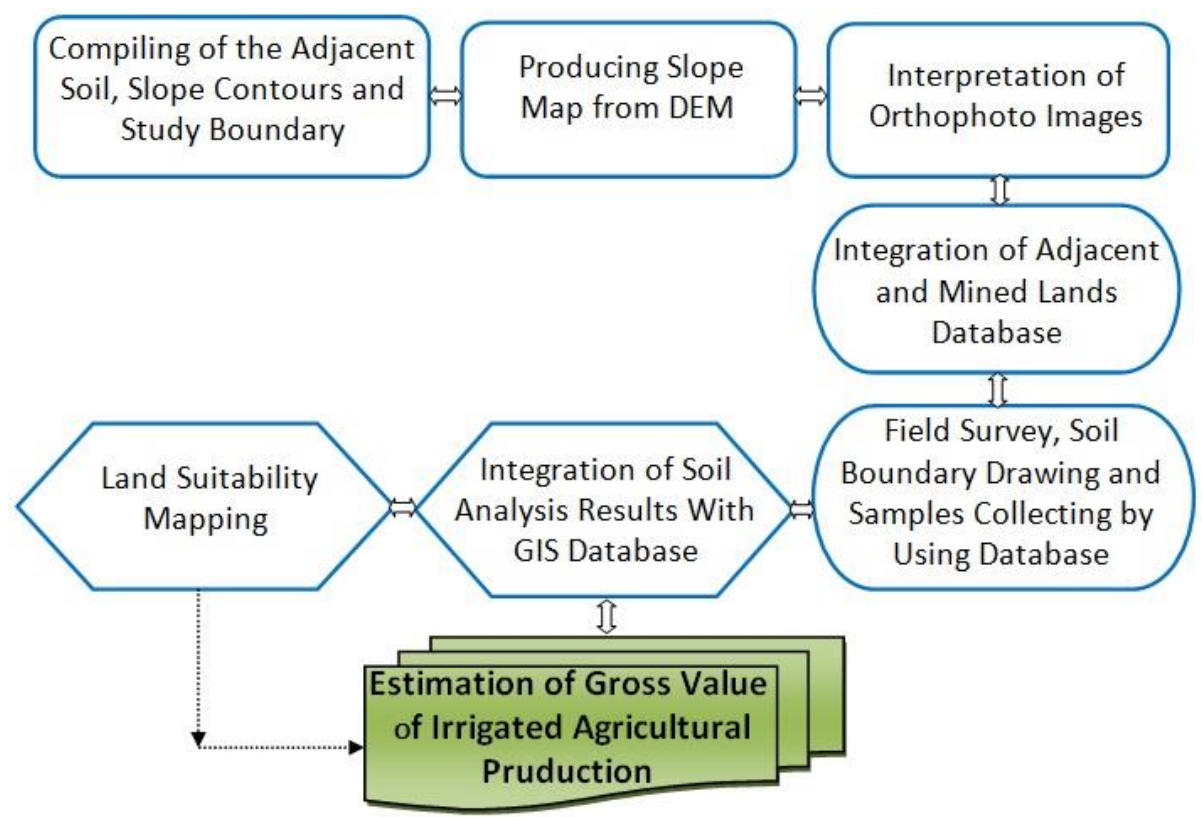

Figure 2- Flow chart used in the study

The soil analysis data, observations in the field survey and the land capability class (LCC) map (1:25.000 scaled) were integrated into the GIS. The LCC map was prepared based on inherent soil characteristics, land features, and environmental factors.

The land suitability map of the study area was prepared in GIS environment using the land database and the results of soil analysis according to the guidelines of FAO (FAO 1976). Soil capability classes, soil depth, slope levels, and soil analysis results of 68 soil samples (the lowest and the highest values) were the main parameters used to determine soil suitability (Table 1).

Table 1- Land suitability classes and their characteristics

\begin{tabular}{|c|c|c|c|c|c|c|c|}
\hline $\begin{array}{c}\text { Soil Depth } \\
(\mathrm{cm})\end{array}$ & $\begin{array}{c}\text { Slope } \\
\text { Classes (\%) }\end{array}$ & $\begin{array}{l}O M \\
(\%) \\
\end{array}$ & $\begin{array}{c}p H \\
\text { (Sat. Ext.) } \\
\end{array}$ & $\begin{array}{c}E C \\
\left(d S m^{-1}\right) \\
\end{array}$ & $\begin{array}{l}\text { Texture } \\
\text { Classes } \\
\end{array}$ & $\begin{array}{c}\text { Land Capability } \\
\text { Classes } \\
\end{array}$ & $\begin{array}{c}\text { Suitability } \\
\text { Classes } \\
\end{array}$ \\
\hline$>90$ & $0-3$ & $1.6-2.6$ & $7.94-7.97$ & $0.42-0.6$ & C-CL & I-II & $\mathrm{S} 1$ \\
\hline $30-90$ & $3-6$ & $1.3-1.9$ & 7.93-7.97 & $0.28-0.3$ & CL & III-IV & S2 \\
\hline $10-30$ & $6-25$ & $1.6-3.3$ & $7.96-8.07$ & $0.28-0.4$ & CL & VI-VII & S3 \\
\hline $60-120$ & $0-3$ & $1.5-2.1$ & $7.98-8.03$ & $17.4-22.0$ & C-CL & V & $\mathrm{N} 1$ \\
\hline $0-10$ & $>25$ & $1.1-2.5$ & $7.52-7.66$ & $0.61-0.8$ & CL & VIII & N2 \\
\hline
\end{tabular}

Land suitability classes are divided into order, class, subclass, and unit classes (FAO 1976). Land suitability order is further divided into suitable $(\mathrm{S})$ and not suitable $(\mathrm{N})$ as $S 1=$ highly suitable, $S 2=$ moderately suitable, $S 3=$ marginally suitable, $N 1=$ currently not suitable and $N 2=$ permanently not suitable.

\subsubsection{Gross value trrigated agricultural production (GVIAP)}

Gross value of irrigated agricultural production (GVIAP) was estimated by using integrated land suitability map classes into the GIS database. The gross value of irrigated agricultural production of the study area was estimated by using the formula (1) given by ABS (2008):

GVIAP $=A i \mathrm{X} \frac{\mathrm{Q}}{\mathrm{Ad} / \mathrm{Y} d i f f^{+\mathrm{A} i}} \mathrm{XP}$

Where; $A i$ is the area that will be used under irrigation $(\mathrm{kg}) ; A d$ is the area that is not under irrigation (ha); Ydiff is the yield difference factor; i.e. estimated ratio of irrigated to non-irrigated yield, is the total quantity of yield production (t or kg) and $P$ is the unit price of production ( $\$$ per $\mathrm{t}$ or $\mathrm{kg}$ )

Estimates of GVIAP values are based on production, commodity price, irrigation data for total area which were obtained from the provincial directorate of agriculture and areal researches (Aydoğdu et al. 2018; Parlakçı Doğan 2019). GVIAP was calculated for commonly produced (kg or tonnes) crops of cotton, second crop maize and wheat in the district. 


\section{Results and Discussion}

\subsection{Land suitability mapping}

The land suitability map of the mined areas was prepared with the GIS database analysis compiling all the data set given in Table 1. Although, this data set consisted of seven different parameters (Table 1), the most effective ones in the GIS analysis performed for delineating agricultural suitability of the mined lands were soil LCC and slope layers which were presented on the map given in Figure 3. Using the GIS database and land survey along with the mined land provided the opportunity to draw the LCC map that is a base of suitability classification.

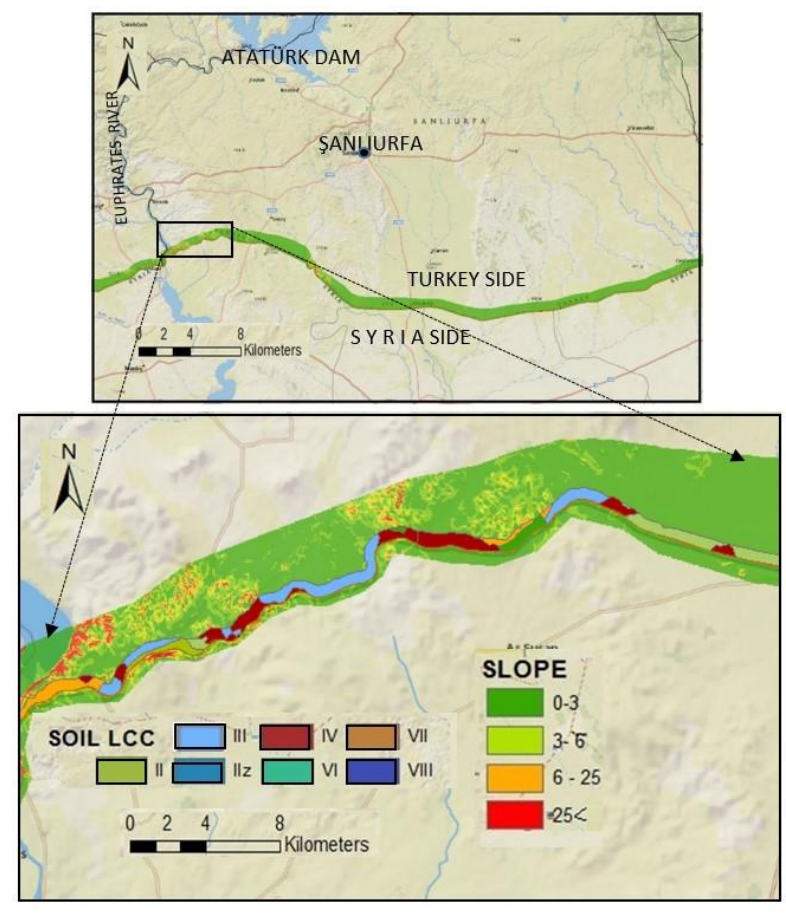

Figure 3- Land capability class and slope map from a selected area

The soil analyses results have been integrated into GIS database for the determination of limiting factors for land suitability classification. The land suitability classes derived from the database along the border are presented in Figure 4.

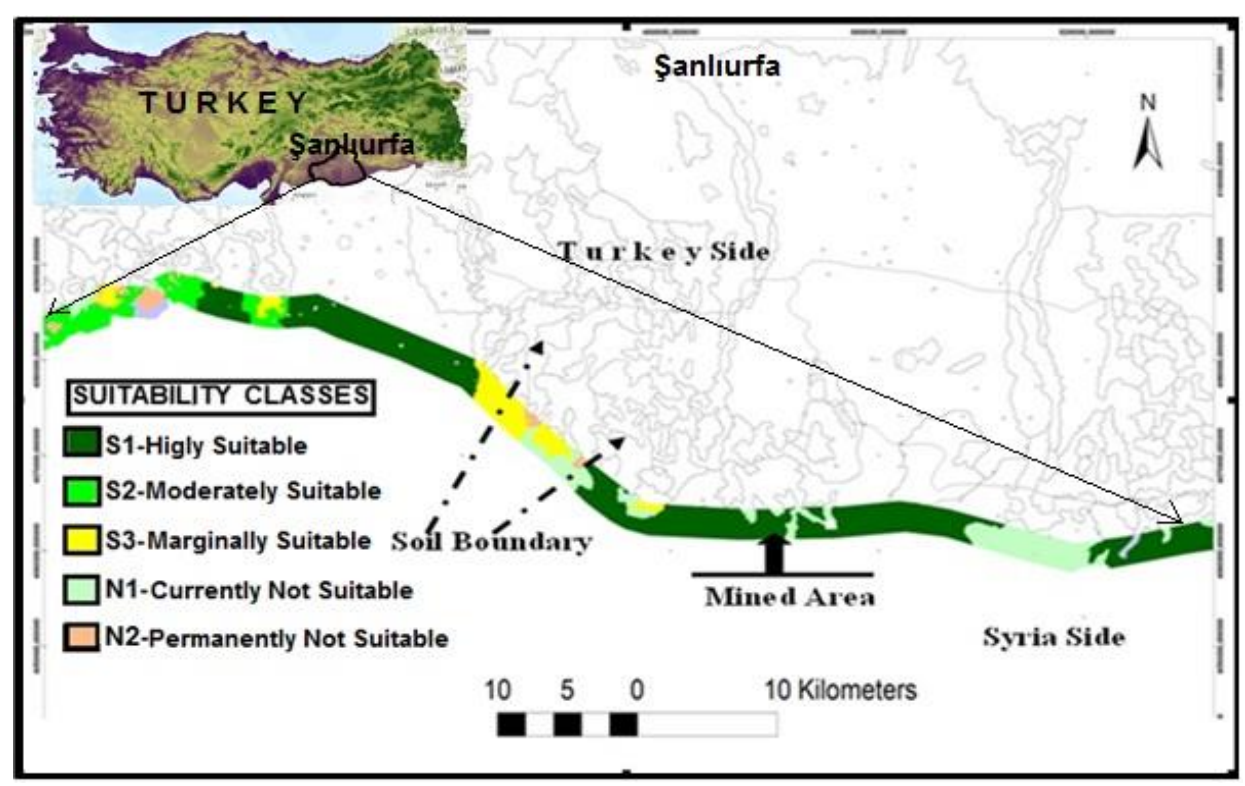

Figure 4- Suitability map of the mined area

The mined lands constituted a total of 6706 ha of which $40.3 \%$ is highly suitable (S1), $49.9 \%$ is moderately suitable (S2), $3.2 \%$ is marginally suitable (S3), 3.7\% is currently not suitable (N1) and 2.9\% is permanently not suitable (N2) (Table 2). 
Limitations such as soil depth, excessive salinity, and high slope constrain the cultivation of several crops. However, the analysis revealed that a considerable part of the land (90.2\%) is classified as S1 and S2 classes indicating highly and moderately suitable for agricultural activities. The information on land suitability is an essential prerequisite for land use planning, (Bandyopadhyay et al. 2009) and sustainable development goals related to food, health, water, and climate (Keesstra et al. 2018). The results indicated that a considerable part of lands within the mined areas are suitable for additional agricultural production. Since the lands were not cultivated for a long time, they can be more productive compared to continuously cultivated lands.

\subsection{Land evaluation and GVIAP prediction}

The mapped areas, which adjacent to water resources and dominated by highly and moderately suitable (S1 and S2) classes were identified as highly suitable to the production of cotton, wheat, barley, corn, soybean, sunflower, and vegetables. While marginally suitable (S3) lands with the shallow depth and high slope gradient were designated as suitable for pistachio, vineyard, olive and, fig orchards. The lands characterized by shallow rooting soil depth formed over limestone parent materials can be suitable for pistachio, vineyard, and olive fruit trees after crushing hard limestones. Crushing the limestone will create an environment to hold water and roots can better use of the available water in the dry summer periods. Therefore, these lands should not only be used for grazing, wildlife and forestry, but also for the other income-generating crops. Salt affected (salinealkaline) areas, classified as currently not suitable (N1), may be used for salt tolerant-crops such as barley, cotton, and wheat after land reclamation. Other lands (N2), which are located on high slope gradient have shallow soil depth and identified as suitable for settlement, pasture, wildlife, and forestry.

The majority of lands (S1 and S2 suitability classes, 6052 ha) can be taken under irrigated agriculture following the removal of mines and can make a significant contribution to the regional economy.

The gross value of irrigated agricultural production for mined land was estimated by using the GVIAP formula and database of land suitability maps (Table 2).

Table 2- Distribution of the land suitability classes and GVIAPs Values

\begin{tabular}{lrrr}
\hline Land & Total Area & Ratio & GVIAP \\
Suitability & (ha) & $(\%)$ & $($ USD) \\
\hline S1-Highly Suitable & 2702 & 40.3 & 5976824 \\
S2-Moderately Suitable & 3350 & 49.9 & 7410200 \\
S3-Marginally Suitable & 209 & 3.2 & 462308 \\
N1-Currently Not Suitable & 249 & 3.7 & 550788 \\
N2-Permanently Not Suitable & 196 & 2.9 & - \\
Total & 6706 & 100.0 & 14400120 \\
\hline
\end{tabular}

The GVIAP results provide a broad range of data about the value of irrigated agricultural commodities. Using the data collected on agricultural production, GVIAP in terms of the gross value of agricultural commodities were simply produced based on irrigation conditions (ABS 2020). We estimated the potential GVIAP values considering common crops of the region that could potentially be produced in the mined lands after removing mine.

Agriculture has a significant impact on the economy of Turkey, thus rational and sustainable management of irrigation facilities are crucial to develop water and soil resources and increase their contribution to the economy. Soils of the region have been irrigated since 1995 and yield was increased up to three to four-fold following irrigation. After the irrigation within the framework of the Southeastern Anatolia Project (GAP) is an integrated regional development project, agricultural production value-added per hectare was determined as \$182 (Unver 1997). Income hectare-based values were calculated as 1228.14 USD ha $^{-1}$ for Şanlıurfa in 2018 (Aydoğdu et al. 2020). The GVIAP of the mined lands where located at the southern border of Şanlıurfa was estimated as 2212 USD per hectare and 14,4 million USD for total area/year, in the case of the S1 and S2 lands taken under irrigation.

The mined lands have not been used for agricultural activities since 1957 and are expected to have greater soil quality due to accumulation of soil organic carbon and extractable nitrogen contents (Ozturkmen \& Kavdir 2012; Dengiz et al. 2020). Therefore, some parts of these lands can be used for organic agriculture which will increase the value-added compared to conventional agricultural production. Besides, mined lands classified as S3, N1 and N2 groups contributed to the protection of some endemic plants from extinction.

\section{Conclusions}

The growing population exerts pressure on food-producing lands which are continuously decreasing. Knowledge of the land suitability is the most important tool to develop sustainable land management and estimate regional gross value added. 
Determination of land suitability and gross value of irrigated agricultural production considering the conversion of inaccessible lands into agriculture by employing the integrated GIS databases are the major outcomes of the study.

The results indicated the efficiency of GIS analysis in existing and adjacent data integration for mapping and delineating the suitability classes of inaccessible lands. The data derived from the suitability map provides considerable information for the sustainable and economical planning of the mined lands.

Knowing on the potential of lands and soils support the particular uses that have guided to the development of landscapes, accurate land use, industrial investment, and urbanization. Land use potential information supports policy development, planning, and on-ground decision making, and should be consulted when new uses of land are being considered.

\section{Acknowledgements}

The authors express their appreciation to Harran University (HUBAP) and Southeastern Anatolia Project Regional Development Administration for the funds.

\section{References}

ABS (2008). Methods of estimating the gross value of irrigated agricultural production. Australian Bureau of Statistics. Information paper (Brian Pink). Austria. w ww. a b s . g o v. a u. ABS Catalogue No. 4610.0.55.006

ABS 2020. Gross value of irrigated agricultural production, 2017-18. Australian Bureau of Statistics. 4610.0.55.008

Aydoğdu M H, Karli B, Parlakci Dogan H, Sevinc G, Eren M E \& Kucuk N (2018). Economic analysis of agricultural water usage efficiency in the GAP-Harran Plain: Cotton production sampling, Sanliurfa-Turkey. International Journal of Advances in Agriculture Sciences 12: $12-19$

Aydoğdu M H, Sevinç M R, Cançelik M, Parlakçı Dogan H, Şahin Z (2020). Determination of farmers' willingness to pay for sustainable agricultural land use in the GAP-Harran Plain of Turkey. Land 9: 261. doi.org/10.3390/land9080261

Bandyopadhyay S, Jaiswal R K, Hegde V S \& Jayaraman V (2009). Assessment of land suitability potentials for agriculture using a remote sensing and GIS based approach. International Journal of Remote Sensing 30: 879-895. doi.org/10.1080/01431160802395235

Bilgili A V, Yeşilnacar İ, Akihiko K, Nagano T, Aydemir A, Hızlı H S \& Bilgili A (2018). Post-irrigation degradation of land and environmental resources in the Harran Plain, Southeastern Turkey. Environmental Monitoring and Assessment 190: 660. doi: 10.1007/s10661-018-7019-2.

Bodaghabadi B, Martínez-Casasnovas J A, Khakili P, Masihabadi M H \& Gandomkar A (2015). Assessment of the FAO traditional land evaluation methods, a case study: Iranian land classification method. Soil Use and Management 31: 384-396. doi.org/10.1111/sum.12191

Camcı Çetin S, Karaca A, Haktanır K \& Yıldız H (2007). Global attention to Turkey due to desertification. Environmental Monitoring and Assessment 128: 489-493. DOI:10.1007/s10661-006-9342-2

Çullu M A, Aydemir S, Qadir M, Almaca A, Öztürkmen A R, Bilgic A \& Ağca N (2010). Implication of groundwater fluctuation on the seasonal salt dynamic in the Harran Plain, South-Eastern Turkey. Irrigation and Drainage 59: 465-476. doi.org/10.1002/ird.507

Çullu M A, Günal H, Akça E \& Kapur S (2018). Soil Geography. In: Kapur S, Akça E, Günal H (Eds). The Soils of Turkey, 105-110. World Book Soil Series, Springer

Dengiz O, İç S, Saygın F \& İmamoğlu A (2020). Assessment of soil quality index for tea cultivated soils in ortaçay micro catchment in Black Sea Region. Journal of Agricultural Sciences - Tarım Bilimleri Dergisi- 26(1): 42-53. doi.org/10.15832/ankutbd.468900

Dinç U, Şenol S, Sayın M, Kapur S, Güzel N, Derici R, Yeşilsoy M Ş, Yeğingil İ, Sarı M, Kaya Z, Aydın M, Kettaş F, Berkman A, Çolak A K, Yılmaz K, Tunçgögü̈s B, Çavuşgil V, Özbek H, Gülüt K Y, Karaman C, Dinç O \& Öztürk N (1988). Soils of Southeastern Anatolia Region. (GAT) 1. Harran Plain. TUBİTAK guided final research project of agriculture and forestry group. Project No:TOAG-534. (in Turkish with an abstract in Engilish)

DMI (State Meteorological Service) (2011). http://www.dmi.gov.tr/veridegerlendirme/ilve-ilceleristatistik.aspx?m= Sanlıurfa (in Turkish)

ESRI (2008). Introduction to ArcGIS desktop and ArcGIS engine development. http://www.esri.com

FAO (1976). A framework for land evaluation: Soils Bulletin 32, Food and Agriculture Organization of the United Nations, Rome, Italy

FAO (1977). A Framework for land evaluation. International Institute for Land Reclamation and Improvement/ILRI. Publication 22. Wageningen. The Netherlands

FAO 2007. Land evaluation towards a revised framework. Food and Agriculture Organization of the United Nations, Rome, Italy

Gallo A, Spiandorella M \& Bini C (2014). A GIS based methodology for land suitability evaluation in Venoto (NE Italy). Environmental Quality 16: 1-7. DOI: 10.6092/issn.2281-4485/4554

IUSS Working Group WRB (2015). World reference base for soil resources 2014, update 2015 international soil classification system for naming soils and creating legends for soil maps. World soil resources report No. 106. FAO, Rome

Kapur S, Sayın M, Gülüt K, Şahan Y, Çavuşgil V, Yılmaz K \& Kahraman C (1991). Mineralogical and micromorphological properties of widely distributed soil series in The Harran Plain. TÜBİTAK Project no: TOAG-534. (in Turkish with an English abstract)

Keesstra S, Mol G, De Leeuw J, Okx J, de Cleen M \& Visser S (2018). Soil-related sustainable development goals: Four concepts to make land degradation neutrality and restoration work. Land 133: 2-20

KHGM (1995). Land existence of Şanlıurfa province. Republic of Turkey Premiership General Directorate of Rural Service provincial report. No: 63. (in Turkish)

Kılıç Ş (2011). Agroecologic land use potential of Amik Plain. Turkish Journal of Agriculture and Forestry 35: 433-442

OSB (2016). Turkey land degradation neutrality national report 2016-2030. Ministry of Water and Forestry, pp. 6-7

Ozturkmen A R \& Kavdir Y (2012). Comparison of some quality properties of soils around land-mined areas and adjacent agricultural fields. Environmental Monitoring Assessment 184: 1633-1643. doi.org/10.1007/s10661-011-2066-y

Parlakçı Doğan H (2019). Comparative economic analysis of two different irrigation resources for field plants: Harran Plain sampling. Harran University journal of engineering. Harran University journal of engineering. 4: 44-49 (in Turkish with an abstract in English) 
Pramanik M K (2016). Site suitability analysis for agricultural land use of Darjeeling district using AHP and GIS techniques. Modelling Earth Systems and Environment 2: 1-22. DOI:10.1007/s40808-016-0116-8

Soil Survey Staff (2010). Keys to soil taxonomy. USDA Natural Resources and Conservation Service, 11th Edition. 1400 Independence Ave. S. W. Washington, D.C. 202509410

Unver O (1997). Southeastern Anatolia project (GAP). International Journal of Water Resources Development 13: $453-484$. DOI.org/10.1080/07900629749575

Yalew S G, van Griensven A, Mul M L \& van der Zaag P (2016). Land suitability analysis for agriculture in the Abbay Basin using remote sensing, GIS and AHP techniques. Modelling Earth System and Environment 2: 101. doi.org/10.1007/s40808-016-0167-x

Zhang C, Jordan C \& Higgins A (2007). Using neighborhood statistics and GIS to quantify and visualize spatial variation in geochemical variables: An example using $\mathrm{Ni}$ concentrations in the topsoils of Northern Ireland. Geoderma 137: 466-476. DOI: $10.1016 /$ j.geoderma.2006.10.018

(C) 2022 by the author(s). Published by Ankara University, Faculty of Agriculture, Ankara, Turkey. This is an Open Access article distributed under the terms and conditions of the Creative Commons Attribution (CC BY) license (http://creativecommons.org/licenses/by/4.0/), which permits unrestricted use, distribution, and reproduction in any medium, provided the original work is properly cited. 